\title{
СТРАТЕГІЇ ПИСЬМА В УКРАЇНСЬКІЙ ЕМІГРАЦІЙНІЙ ПОЕЗІЇ: БОГДАН РУБЧАК VS ЮРІЙ ТАРНАВСЬКИЙ
}

\author{
АНДРІЙ ДРОЗДА \\ Львівський національний університет імені Івана Франка, Львів - Україна
STRATEGIE POETYCKIE W UKRAIŃSKIEJ POEZJI EMIGRACYJNEJ: JURIJ TARNAWSKI VS BOHDAN RUBCHAK \\ ANDRIJ DROZDA \\ Narodowy Uniwersytet imenia Iwana Franki we Lwowie, Lwów - Ukraina

\begin{abstract}
STRESZCZENIE. W artykule zostały poddane analizie aspekty unowocześniania języka poetyckiego w twórczości członków Grupy Nowojorskiej. Na podstawie tekstów Bohdana Rubczaka i Jurija Tarnawskiego autor bada przyczyny konfliktu między poezją tradycyjną a modernistyczną, poszukiwania indywidualnych środków ekspresji oraz tworzenie nowej estetyki. Odrębna uwaga została poświęcona także wpływom, które wywarły na twórczości poetów Grupy Nowojorskiej ważne idee filozoficzne oraz lingwistyczne.
\end{abstract}

\section{WRITING STRATEGIES IN UKRAINIAN ÉMIGRÉ POETRY: YURIY TARNAWSKY VS. BOHDAN RUBCHAK}

\author{
ANDRII DROZDA \\ Ivan Franko Lviv National University, Lviv - Ukraine
}

ABSTRACT. The article analyzes selected aspects of poetry language renovation in the works by members of the New York Group. The author considers the causes of the conflict between traditional and modernist poetry, examines new means of expression and aesthetics creation, investigates the influence of prominent philosophic and linguistic ideas in works of the New York Group.

$\mathrm{H}$ ью-Йоркська Група дедалі впевненіше утверджується в українському літературному каноні як визначне явище поетичного модернізму та новаторства. Дослідники творчості учасників групи - зокрема, Марія Ревакович, Тадей Карабович, Ірина Лівенко, Володимир Моренець, Ігор Котик, Марія Котик-Чубінська - звертають увагу на внесок „нью-йоркців” у розвиток мови української поезії. Проте повного дослідження характеру поетичного новаторства, особливостей конфлікту між традиційною поетикою й естетичними поглядами нового покоління еміграційних літераторів, яке представляла Нью-Йоркська Група, досі не маємо, тож змушені звертатись передусім до автокоментарів самих учасників групи, викладених у нечисленних статтях та інтерв'ю. Чи не найбільш активними тлумачами засадничих принципів твор- 
чості цієї поетичної формації стали головні її теоретики та організатори: Богдан Бойчук, Юрій Тарнавський та Богдан Рубчак. Відзначаємо при цьому, що естетична платформа Нью-Йоркської Групи ніколи не була зафіксована у вигляді маніфесту, а поетична практика кожного з іiі учасників є цілком оригінальною та несхожою на тексти решти „нью-йоркців”.

Проте окрім організаційних причин, як-то взаємодопомога у виданні нових творів чи особиста симпатія та дружба, учасників групи, безумовно, об'єднували передусім суто мистецькі завдання, найважливішим з яких було наблизити українську поезію до кращих світових зразків модернізму. Досягти такого надзавдання було можливо лише за умови радикального оновлення мови української поезії. Дискусія на тему, якою має бути нова українська література і нова поезія, зокрема, тривала від початку XX століття і була перервана спочатку репресіями проти літераторів у 1930-х рр., які ввійшли в історію як Розстріляне Відродження, а потім Другою світовою війною. Дебати розгорілися 3 новою силою в таборах „переміщених осіб” на території Німеччини, де наприкінці 40-х років діяв Мистецький Український Рух. Більшість теоретиків МУРу пізніше увійшли до об'єднання „Слово” (США), яке зосередилось на вирішенні організаційних питань. У збірниках „Слова” зустрічаємо теоретико-літературні публікації колишніх МУРівців (Уласа Самчука, Івана Багряного, Юрія Шевельова, Василя Барки, Ггоря Костецького), проте вони, як правило, позбавлені колишньої гостроти та конфліктності. Провідні літературні критики „Слова” Григорій Костюк та Юрій Лавріненко поділяли панівні в середовищі діаспори консервативні настрої щодо мови та культури. I хоч Ю. Лавріненко прихильно відгукнувся про перші публікації „нью-йоркців”, із куди більшим ентузіазмом він привітав появу українських шістдесятників. У своїх спогадах про це відкрито пише Богдан Бойчук:

Було дві причини, які спонукали занепад нашої зовнішньої діяльності. Першою причиною були шістдесятники, які тотально опанували літературну арену в Україні й у діаспорі. Всі діаспорні критики були захоплені шістдесятниками, бо вони відроджували їхню молодість, тобто поетику й вітаїзм двадцятих років. А Нью-Йоркська Група суцільно розчарувала їх, тобто критиків, не повернулася до традицій „розстріляного відродження", як вони надіялися й унапрямлювали нас, ані не зайняла патріотично-політичних позицій ${ }^{1}$.

Про ситуацію заочного протистояння між Нью-Йоркською Групою та шістдесятниками, яке започаткувала та розвинула еміграційна критика, згадує також і Юрій Тарнавський, та одночасно співзасновник Нью-Йоркської Групи звертає увагу на обмеженість читацької аудиторії в еміграції:

Журнал „Сучасність”, в якому, як було сказано, найчастіше друкувалися члени групи, виходив накладом біля 2000 примірників. Але це не значило, що всі з тих, хто купував журнал, сприймали твори групи. До редакції часто надходили скарги на них, 3 погро-

${ }^{1}$ Б. Б о й ч у к, Спомини в біографiї, Київ 2003, с.146. 
зами, що передплата буде відкликана, якщо таке дальше будуть друкувати. [...] Після теплого привітання перших книжок групи деким зі старшого покоління письменників (Ігор Костецький, Василь Барка і особливо Вадим Лесич) та критиків (насамперед Юрій Лавріненко), прийшла байдужість, притаманна всьому сучасному суспільству, не тільки українському. Були теж в'їдливі та примітивні напади з боку старшої генерації (Вадим Сварог, Борис Олександрів), які, наперекір авторам нападів, надавали групі сили - 3 примітивізмом треба було боротися, а коли тебе помічають, значить, ти ще живий. Мовчанка була найболючішою. [...] Тоді вийшли на сцену в Україні шістдесятники. Еміграція зареагувала на них оргазмово. [...] Окреслювалися шістдесятники критиками і читачами як „модерністи” (нараз модернізм полюбили), що вказує, яке уявлення про модернізм мав український літературний світ того часу. „Модернізм” шістдесятників контрастувався з модернізмом Нью-Йоркської Групи як „справжній, український”, тоді як цей останній був „штучним, неукраїнським”2.

Навіть нейтральний у своєму ставленні до „нью-йоркців” літературний критик Григорій Костюк все ж виказує певні підозри щодо їхнього бачення модернізму, протиставляючи поетиці групи творчість шістдесятників у вступній промові до симпозіуму ОУП „Слово” на тему Традиція й новаторство, що відбувся 1964 року: „Треба уміти розрізняти глибину й поверховість. Органічність і штучність. Справжній брильянт і підроблений камінчик”з. Один 3 ,адвокатів” та практиків українського модернізму в еміграції Ігор Костецький зауважив цю недовіру до нової літератури і поезії зокрема: „Якщо рахувати статистично, то стане ясно, що твори так званих «експериментаторів», або «модерних», у виданнях «МУРу» і «Слова» перебувають у постійній меншості»4. Костецький застерігав, що подібне ставлення до молодих модерністів у колах української еміграції, яке проявляється в ігноруванні або ж агресивній безпідставній критиці, може призвести до відходу цього покоління від літератури:

Женя Васильківська може стати лікаркою в якомусь містечку Оклагоми. Юрій Тарнавський візьме участь у проєкті електрифікації Ассуанської греблі. Рубчак пожне лаври при фантастичному нападі на плянету Венеру. Богдан Бойчук стане отаманом гангстерів у Чікаго. Кожен, отже, знайде для себе позалітературне зайняття. Настане епоха тотального вимирання „модерністів”, які декому отруюють існування. Але що ж тоді? Чи буде тоді все в порядку з українською літературою?

Відповідей на ці риторичні запитання, на щастя, так і не було отримано, адже більшість учасників Нью-Йоркської Групи не відмовилися від свого поетичного покликання і всупереч несприятливій для творчості ситуації продовжували писати і видавати нові твори. Сдиним винятком можна вважати згадану

${ }^{2}$ Ю. Т а р н а в с ь к и й, Акварій у морі, [в:] його ж, Квіти хворому, Львів 2012, c. $114-116$.

${ }^{3}$ Г. К о с т ю к, До постави проблеми, [в:] „Слово” 1968, № 3, с. 474.

${ }^{4}$ I. К о с т е ц ь к и й, Про єдність різноманітного й суперечливого, [в:] „Слово” 1962, № 1 , c. 322 .

${ }^{5}$ Там само, c. $324-325$. 
Костецьким Женю Васильківську, яка після чудової дебютної збірки Короткі віддалі (1959) не опублікувала жодної поетичної книги.

Слід відзначити, що конфлікт між об’єднанням „Слово” та Нью-Йоркською Групою виник не на початку і навіть не в середині 1960-х років, а відразу ж після першого з’їзду 1958 року. Богдан Бойчук відгукується про цю подію так:

Нашому розчаруванню не було меж. Багряний довго говорив про потребу позитивного героя в сучасній прозі, на кшталт соцреалізму. Самчук же справді говорив красиво, але під гарними словами не було глибини. [...] На з'їзді не було нового й свіжого подиху, якого ми шукали, не було хоч відгомону ідей, які нуртували в тодішньому світі. Тому цей з'їзд став переломним у наших взаєминах зі „Словом”. Ми раптово й категорично вирішили йти окремою дорогою ${ }^{6}$.

Проте якою саме мала бути ця дорога, ще треба було вирішити. Деякі учасники Нью-Йоркської Групи вже дебютували окремими поетичними збірками, інші лише збиралися з силами, щоб подати свій голос на захист нової естетики. Молоді поети в еміграції мусили боротися не лише 3 несприйняттям консервативного оточення діаспори, а й з мовними факторами. Віра Вовк, яка приєдналася до Нью-Йоркської Групи в 1958 році, вже маючи в своєму доробку декілька поетичних збірок, згадує про гостру проблему вивчення української мови, яка постала перед іiі ровесниками:

Ми, молоді, що виростали на чужині, в іншомовному оточенні, випускники різнорідних шкіл, ще боролися із труднощами української синтакси й українськими наголосами, куди вдиралися варваризми германізмів, англізмів, латинізмів [...] Все ж таки ми не піддавалися, шукали $[\ldots]^{7}$.

Хоча кризу в літературі та доконечну потребу змін визнавали, здавалося, всі, проте старше покоління літераторів так і не відійшло від пошуку універсальних естетичних, а частіше ідеологічних моделей, які мали б вивести всю українську літературу на новий рівень. Настрій цих дискусій передано в спогадах Віри Вовк:

Постійною темою була поезія: як переживе українська Муза серед усесвітніх літературних течій? Маланюк завзято обстоював героїку, ставлячи за приклад Оксану Лятуринську й Олену Телігу, Кравців боронив наш фольклор і радив на ньому будувати нові споруди. [...] Гординський прислухувався й рідкісно обзивався своїм гугнявим голосом [...]. Я була обзнайомлена 3 його поезією й ставила іï десь поблизу неоклясиків. Поважала їі, але не захоплювалася нею, бо вважала, як і досі вважаю, що кожна доба витворює своє притаманне обличчя, свою мистецьку мову, - у цьому була зовсім згідна зі своїми новими друзями з Нью-Йоркської Групи ${ }^{8}$.

\footnotetext{
${ }^{6}$ Б. Б о й ч у к, зазнач. праця, с. 47.

${ }^{7}$ В. В о в к, Мережа, Київ 2011, с. 28.

${ }^{8}$ Там само, с. 27.
} 
Гостра потреба пошуку власного поетичного голосу виникала і в Богдана Бойчука, проте віднайти свій стиль йому вдалося не відразу. Бойчук зізнається, що важливу роль в становленні його як поета-модерніста відіграв саме Юрій Тарнавський, котрий виявився серед учасників „групи молодих”, як іноді ще називали „нью-йоркців”, найбільш рішучим та радикальним у своїй поетичній практиці:

Я далі продовжував висловлюватися традиційними формами, але не був задоволений написаним. Я не мав відчуття, що ці мої вірші були цілком моїми. Мені здавалося, що я говорив не своїм голосом, хоч подекуди в моїх тодішніх віршах провлялися характерні для мене експресивні образи. Юрій Тарнавський при кожній нагоді говорив мені, що я не можу так писати, бо я не $є$ таким як мої поезії. Я не знав справді ким я $\epsilon$, тому й не міг збагнути, що Тарнавський мав на думці, та як я мав висловлювати себе 9 .

Б. Бойчук звертає увагу на те, що дорога молодих поетів до нової поетичної мови пролягала передусім через практичну творчість, а за теоретичні узагальнення наприкінці 1950-х учасники групи не бралися.

На противагу „нью-йоркцям”, представники старшого покоління проявляли себе переважно у теоретичних диспутах та публікаціях. Більшість із них так і не відмовилися від ідей творення „великої літератури”, „органічної” за своєю формою та змістом із національною традицією, такої літератури, що мала б презентувати Україну в світі, а отже, виконувати певні політичні завдання. Поети Нью-Йоркської Групи свідомо відкидали такі „великі ідеї”, пропонуючи натомість індивідуальний пошук поетичного голосу. Відтак - жодних маніфестів та теоретичних програм. 3 іншого боку, припускаємо, що на час заснування та в перші роки діяльності групи, жоден з ії учасників не був спроможний або ж не вважав за необхідне публікувати особистий теоретичний маніфест. Лише трохи пізніше, у 1960-х роках, дехто з учасників групи врешті розпочав теоретичний та літературно-критичний дискурс, присвячений творчості колег чи власним текстам. Йдеться насамперед про публікації Богдана Рубчака, Богдана Бойчука та Юрія Тарнавського. 1971 року Ю. Тарнавський публікує в журналі „Сучасність” велику статтю Література $і$ мова, яку можна вважати інтелектуальною платформою літературної діяльності цього автора. Проте і щодо Тарнавського, і щодо інших учасників Нью-Йоркської Групи діє незмінне правило - спочатку практика, а вже потім теорія. Цілком логічно, що на початку своєї творчості молоді поети взорувались на ідеї та здобутках класиків світового модернізму, хоча окремі критики вважали це за суттєвий недолік творчості „нью-йоркців”:

[...] поетичні моделі, що їх ця группа перебрала (Еліот, Лорка), вже тоді були старуваті. Тепер вони зовсім несучасні. А якщо ціль - бути співзвучним із західною поезією, то де найновіші зразки? А що важливіше: де сучасна доречність? ${ }^{10}$.

${ }^{9}$ Б. Б о й ч у к, зазнач. праця, с. 40.

${ }^{10}$ Г. Г р а б о в и ч, Від мітів до критики. Дещяо про аналізу Рубчака та поезію Патриції Килини, [в:] „Сучасність” 1969, № 5, с. 86. 
Так висловлювався Григорій Грабович наприкінці 1960-х років про естетичні орієнтири групи. Критику Г. Грабовича можна зрозуміти, оскільки приблизно у той самий час, коли виходили перші публікації Нью-Йоркської Групи, голосно заявило про себе нове покоління американської поезії: групи Біт, Чорна Гора, Нью-Йоркська Школа та інші молоді поети, які заперечували „еліотівську” модель поезії і намагалися знайти нову природну мову. Безумовно, учасники Нью-Йоркської Групи були обізнані з цією поезією. Про це свідчить стаття Богдана Рубчака Парнас коміть-головою. Путівник по лябіринтах нової американської поезії, що вийшла в журналі „Сучасність” 1972 ро$\kappa^{11}$. Богдан Бойчук ${ }^{12}$ та Юрій Тарнавський ${ }^{13}$ згадують про бурхливу мистецьку атмосферу 1950-60-х років у США та про покоління „бітників” зокрема. Учасниця й дослідниця групи Марія Ревакович стверджує наявність певних впливів американського поетичного середовища на Нью-Йоркську Групу:

Американський літературний грунт кінця 1950-х років не поступався мистецтву динамічністю. Це був час, який народив, наприклад, так звану „біт генерацію”, і всі ті ферментування, які тоді відбулися, знов-таки, не могли не впливати на начитаних молодих поетів ${ }^{14}$.

Схожі думки висловлюють також Соломія Павличко ${ }^{15}$ i Тамара Гундорова ${ }^{16}$. Проте єдина посутня спроба компаративістичного аналізу поезії Нью-Йоркської Групи та їі американського оточення - стаття Лізи Ефімов-Шнайдер Поезія Нью-Йоркської Групи: українські поети в американських лаштунках ${ }^{17}$ (1981) все ж не дає відповіді на важливе запитання: чому оновлюючи мову поезії „нью-йоркці” не використовували живу розмовну мову так активно, як американські поети 1950-х? Вирішити цю проблему допомагає стаття Богдана Рубчака Дім як муиля: украӥнська еміграиійна поезія ${ }^{18}$, де автор акцентує на ситуації існування поета-емігранта в культурному та мовному гетто, яке часто $€$ його єдиним притулком.

${ }^{11}$ Б. Р у б ч а к, Парнас коміть-головою. Путівник по лябіринтах нової американської поезії, [в:] „Сучасність” 1972, № 1, с. 29-50.

${ }^{12}$ Б. Б о й ч у к, зазнач. праця, с. 100

${ }^{13}$ Ю. Т а р н а в с ь к и й, Босоніж додому $і$ назад, [в:] його ж, Не знаю, Київ 2000 , c. $297-298$.

${ }^{14}$ М. Р е в а к о в и ч, Дещчо про Нью-Йоркську Групу, [в:] її ж, Persona non grata. Нариси про Нью-Йоркську групу, модернізм та ідентичність, Київ 2012, с. 21.

${ }^{15}$ С. П а в л и ч к о, Дискурс модернізму в украӥнській літературі, [в:] іï ж, Теорія літератури, Київ 2009, с. 383.

${ }^{16}$ Т. Г у н д о р о в а, Дещчо про модернізм та дядька в Києві, [в:] „Критика” 2010, № $1-2$, c. $38-39$.

${ }^{17}$ L. E f i m o v - S c h n e i d e r, Poetry of the New York Group: Ukrainian Poets in an American Setting, [в:] "Canadian Slavonic Papers" 1981, no. 23, p. 291-301.

${ }^{18}$ B. R u b c h a k, Homes As Shells: Ukrainian Émigré Poetry, [в:] New Soil-Old Roots. The Ukrainian Experience in Canada, Winnipeg 1983, p. 87-123. 
Американські поети, перебуваючи в живому, динамічному мовному середовищі, мали змогу відстежувати буденні прояви „вуличноі” мови і синтезувати 3 цих фрагментів нову мову поезії. Натомість українські молоді поети 3 Нью-Йоркської Групи вивчали рідну мову самотужки, а рецепція їхньої творчості в колах консервативної діаспорної спільноти межувала 3 нерозумінням, ігноруванням та агресивним запереченням будь-яких експериментів. Функція захисту культурної та мовної традиції нерідко починає домінувати в умовах вимушеної еміграції, тож новаторство та експеримент можуть сприймати як загрозу. 3 цього погляду цілком закономірним виглядає той факт, що чи не найбільш привітно зустрів дебютні публікації Нью-Йоркської Групи не український критик, а польський - поет Юзеф Лободовський у паризькому часописі „Культура” 1960 року відзначив світлі, життєствердні настрої поезії українських поетів в еміграції і назвав їх „молодим лісом на чужині" 19 . У схожому ключі охарактеризував поезію „нью-йорківців” інший критик, що проживав у Франції, Емануїл Райс: „Їм не властивий в’ялий песимізм деяких західних колег - сюрреалістична «чорнота» і неминучий хаос «автоматичного» письма" ${ }^{20}$. Похмурі мотиви позначені впливом філософії екзистенціалізму все ж не рідкість у поезії Юрія Тарнавського, проте Емануїл Райс найбільше уваги приділив аналізу творчості Емми Андієвської, яка в естетичній парадигмі Нью-Йоркської Групи перебуває на протилежному від Юрія Тарнавського полюсі. Е. Райс виводив генеалогію творчості Емми Андієвської через поезію Володимира Свідзінського, Павла Тичини й Богдана Ігоря Антонича. Тож Емануїл Райс, як і Богдан Рубчак, вписують творчість Емми Андієвської в одну традицію, що полягає в ускладненні поетичної мови. Б. Рубчак висловив таке спостереження в статті Поезія антипоезії (1966), присвяченій аналізу творчості Юрія Тарнавського:

Ще в перші роки минулої декади, скажемо, між 1952-1954 роками, думалося, що українську поезію треба писати тільки канонізованою українською мовою. Справа, звичайно, не в модернізмі поезії, не в новаторстві засобів. Справа тільки в мові. Чомусь думалося, що вся українська поезія мусить виростати на українських мовних традиціях, на традиціях народної чи історичної мови, що на них виросла поезія Тичини, Бажана, Маланюка, Лятуринської, Лесича - чи навіть домежно модерних Барки й Андієвської, яка тоді виступила з блискучою першою збіркою. Ті, хто спорадично хотів виламуватися $з$ мовних рамок народної творчости та ії дитини - українського романтизму, - часто зустрічалися з фатальними творчими катастрофами ${ }^{21}$.

Абсолютній більшості молодих поетів, на думку Б. Рубчака, було вкрай важко при створенні свого поетичного світу обійтися без двох стовпів української традиції - фольклору та романтизму. До них наважимося додати й сентимен-

${ }^{19}$ Ю. Т а р н а в с ь к и й, Акварій у морі..., зазнач. праця, с. 100.

${ }^{20}$ Е. Р а й с, Класицизм і модернізм в украӥнській поезії, [в:] „Терем” 1966, № 2, с. 30.

${ }^{21}$ Б. Р у б ч а к, Поезія антипоезї. Загальні обриси поезії Юрія Тарнавського, [в:] його ж, Міти метаморфоз, або Пошуки доброго світу, Львів 2012, с. 308. 
талізм: його доводилося долати задля модернізації поезії. Сентиментальні, стилізовані під фольклор кліше, що заводили традицію в глухий кут, висміював у своєму вірші Iсторія інший український поет в діаспорі Богдан Нижанківський, котрий публікував свої тексти під псевдо Бабай. Історія починається зі строфи:

\author{
Прощав ліричний козаченько \\ (Під ним ліричний кониченько) \\ Свою ліричну дівчиноньку \\ Бо на ліричну йшов війноньку
}

Використовуючи пестливі суфікси, тавтологію та фольклорний сюжет, автор досягає комічного ефекту, а після смерті „ліричного” героя у другій стофі завершує свій вірш „убивчим” вердиктом:

Лірично сохла дівчинонька...

Ось українська пригодонька! ${ }^{22}$.

У поезії Нью-Йоркської Групи іронії зовсім не так багато, як у віршах Бабая, проте і Юрій Тарнавський, і Богдан Рубчак у своїй творчості долали збиті кліше „поезії”, намагаючись, як висловився Б. Рубчак „писати по можливості добру і по можливості власну поезію”²3. Звісно, для досягнення такої мети потрібна була нова мова, і роль Тарнавського у пошуку такої мови стала визначальною. На думку Б. Рубчака, спрощення й ускланення - це два можливі шляхи до оновлення поетичної мови:

Поетично змінювати українську мову доводиться двома протилежними шляхами: iii можна згущувати, затінювати і ускладнювати або можна іiі до меж випрозорювати, спрощувати, нейтралізувати. Перший шлях українському поетові дається легше, бо в своїй природі наша мова - мова барокових складностей, лабіринтичностей, вензелів, синтаксично-лексичних пригод. [...] можна, максимально спрощуючи і „нівелюючи” нашу мову, - відводити іiї від іiї природи, від іiї центру, і так іiї інтернаціоналізувати. $[\ldots]$ Юрій Тарнавський вибрав цей важчий шлях ${ }^{24}$.

Богдан Рубчак не шкодує компліментів на адресу колеги, водночас відзначає, що інші учасники групи: Женя Васильківська, Емма Андієвська, Віра Вовк - не пішли в цьому напрямі: „Від своєї першої збірки Андієвська щораз далі йде протилежним шляхом, до серця народної мови. В першій збірці пішов за ним (за Ю. Тарнавським - прим. А. Д.), але вернувся з півдороги" ${ }^{25}$. Щодо поетичної практики самого Богдана Рубчака, то він визнає, що сам залишився

${ }^{22}$ Б. Н и ж а н к і в с ь к и й, Історія, [в:] Поза традииії. Антологія украйнської модерної поезії в діаспорі, Торонто 1993, с. 64.

${ }^{23}$ Б. Р у б ч а к, Від „святих корів” до творчого мислення. Агон з Григорієм Грабовичем, [в:] „Сучасність” 1969, № 9, с.75.

${ }^{24}$ Б. Р у б ч а к, Поезія антипоезї..., зазнач. праця, с. 309-310.

${ }^{25}$ Там само, с. 310. 
при „шевченківських традиціях українського мовного стилю”, 26 проте наголошує на психологічній різниці між своїми юнацькими віршами і текстами доби „після Тарнавського”:

Бо на самому початку п’ятдесятих років я вірив, що мушу писати „поправною” українською мовою, що в українській поезії іншого виходу просто немає. А тепер я вибираю традиційний український підхід до поетичної мови цілком свідомо і навіть часом дозволяю собі на пародійні нотки цих традицій. Значить, існує можливість вибору, яка не існувала для Семенка ${ }^{27}$.

Навіть оглядовий аналіз вже згаданих „пародійних ноток” на традицію в текстах Б. Рубчака і Ю. Тарнавського доводить суттєву відмінність у творчих підходах цих двох авторів: Б. Рубчак веде з традицією шанобливий діалог, хоча й відмовляється від патетичного тону, а Ю. Тарнавський натомість спрямовує інтертекстуальні засоби на заперечення традиції. Наприклад, вірш Б. Рубчака Поетові зі збірки Промениста зрада (1960) містить ознаки діалогу одразу з кількома класиками та поетичними традиціями:

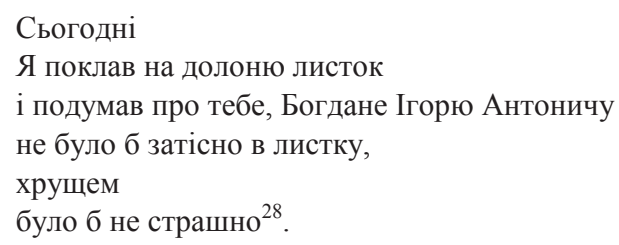

Антонич, до якого прямо звертається ліричний герой, згадуючи й кілька образів 3 його віршів: хрущ, бджола, лисиця, - лише один з учасників цього діалогу. Б. Рубчак також вживає у своєму тексті епітети „ласкаволистий”, „безмежноокий”, які створюють інтертекстуальний місток до Павла Тичини. Ще одним адресатом поетичного діалогу можна вважати американського поета покоління „біт” Алена Гінзберга, відомий вірш якого Супермаркет у Каліфорніі ${ }^{29}$ (1956) розповідає про уявну подорож ліричного героя з Волтом Вітменом. Таким чином Рубчак, як і Гінзберг, звертається до свого великого попередника, використовуючи і творчо переосмислюючи поетикальні засоби цього попередника. Поруч 3 „антоничівськими” образами, Рубчак залюбки використовує „тичинівські” епітети-неологізми: „м'якостопо”, „блакитногрудих”, „синьошата”, „срібнолиця” тощо, вказуючи так на важливі для себе постаті з української поетичної традиції. Культурні коди Рубчакової поезії сягають Далекого Сходу, проходять від Античності через Середньовіччя й Ренесанс аж до світового модернізму XX століття, тож для адекватного відчитування

\footnotetext{
${ }^{26}$ Там само, с. 309.

${ }^{27}$ Там само.

${ }^{28}$ Б. Р у б ч а к, Поетові, [в:] Нью-Йоркська Група. Антологія поезї, прози та есеїсти$\kappa и$, Львів 2012, с. 217.

${ }^{29}$ А. Г і н з б е р г, Супермаркет в Каліфорнії, [в:] День смерті Пані День: американська поезія 1950-1960-х років у перекладах Юрія Андруховича, Харків 2007, с. 86.
} 
багатьох текстів знадобиться потужний інтелектуальний багаж. Тадей Карабович вбачає у цьому спробу продовження культурної традиції, утвердження тяглості „між тим, що $є$ в античній давнині, і тим, що становить його україн-

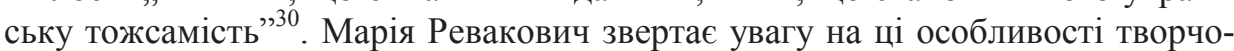
сті Богдана Рубчака, також висновуючи з них бажання зберегти традицію:

Незважаючи на те, що загалом у першій збірці домінують модерністські, екзистенціялістські та суто імажиністські мотиви, уже тут з'являються алюзії, інтертекстуальність i гра 3 культурними символами минулого, що дуже типово для пізнішого Рубчака. [...] Однак ця „присутність минулого” чи інтертекстуальна гра непародійні за природою. Рубчаків діялог із видатними представниками і західноевропейської (Бальзак, Бодлєр, Гете), і рідної української (Вишенський, Котляревський, Франко, Антонич) літературної традицій, а також звернення до відомих літературних героїв (Касандра, Дантова Франческа з п'ятої пісні Пекла, Фавст і Дон Жуан) відбувається лише тому, що автор схиляється перед ними, а не тому, що він хоче поруйнувати велику гуманістську традицію. Я вбачаю у Рубчаковій поезії своєрідну тугу за тяглістю, прагнення зберегти зв'язок із цією культурною скарбницею ${ }^{31}$.

На думку М. Ревакович, у поезії Б. Рубчака досить часто зустрічаються прояви іронії, а то й сарказму та скепсису, проте поетова недовіра до метафізичної суті життя та поезії „не має нігілістського чи деструктивного характеру”з2. Зовсім інше враження створюють деякі тексти Юрія Тарнавського. Зокрема, у вірші Заповіт, який містить явні алюзії на однойменний твір Тараса Шевченка, ліричний герой просить спалити його тіло і розвіяти над морем:

Коли помру, то спаліть

моє тіло, як заборонену, чи зненавиджену книжку,

і зберіть увесь попіл, щоб ні одна молекуля із мене

не залишилася на місці, де згорів.

I йдіть до Сантандеру, до скелі, висуненої найдальше

в море,

і чекайте на сильний вітер із півдня,

і киньте цей попіл в сторону моря, хай сірим прапором

він залопоче хоч на кілька секунд над синьою водою.

І після цього вже ніколи

не думайте про мене і не вимовляйте мого імени,

щоб його букви, як струпи, не тріскали,

і не кривавила ця рана, що під ними, яка ніколи

не загоїться ${ }^{33}$.

${ }^{30} \mathrm{~T}$. K a r a b o w i c z, Scalanie rozbitego świata. Twórczość literacka ukraińskich poetów emigracyjnych „Grupy Nowojorskiej”, Lublin 2008, s. 183.

${ }^{31}$ М. Р е в а к о в и ч, (Пост)модерністські маски: естетика гри в поезї Емми Андієвської та Богдана Рубчака, [в:] іï ж, Persona non grata..., зазнач. праця, с. 103-104.

32 Там само, с. 105.

${ }^{33}$ Ю.Т а р н а в с ь к и й, Поезї про ніщзо і інші поезї̈ на иңю саму тему, Нью-Йорк 1970, c. 307. 
Текст вірша Ю. Тарнавського поділено на три строфи, які є ритмізованими відповідниками до трьох композиційних частин Заповіту Шевченка. Тож у вирішенні форми Тарнавський також іде від супротивного: будує вірш „не так, як у Шевченка", проте послідовно зберігає зв'язок із „першотвором”. Обидва тексти тримаються на повторах наказових дієслів: „спаліть”, „зберіть”, „йдіть”, „чекайте”, „киньте” тощо, які проте мають значення дій протилежних до тих, про які просить Шевченків ліричний герой. Врешті Тарнавський переходить на заперечну форму наказового способу: „не думайте”, „не вимовляйте”. Його ліричний персонаж вимагає забуття й знищення усіх слідів: напротивагу Шевченковому „не забудьте пом'янути”, він бажає бути розвіяним над морем, а не похованим „серед степу широкого, на Вкраїні милій ${ }^{34}$.

Заповіт Ю. Тарнавського - оригінальне заперечення культу й пози Поета, автор знову звертається до мотивів, що звучать ще у його дебютній збірці Життя в місті: „я не поет, бо слова мої грубі, як поліна" ${ }^{\text {, }}$, а Богдан Рубчак створює у поетичних текстах протилежного персонажа. Григорій Грабович цілком слушно характеризує поезію Рубчака як багату „на пози, жести та свідомий екзотизм. На відміну від поета у звичайному житті, там завжди присутній Поет"36. Юрій Тарнавський відмовляється від звання „Поета з великої літери”, як і від конструктивного діалогу з класиками, надаючи перевагу діалогу деструктивному. Тож аналіз поетичних текстів Богдана Рубчака та Юрія Тарнавського демонструє вкрай різний вибір стратегії поетичного письма та оновлення мови: від синтезу важливих елементів традиції до повного іiі заперечення, що вкотре засвідчує різнорідність Нью-Йоркської Групи.

Отож робимо висновок, що учасники Нью-Йоркської Групи обирали несхожі новаторські стратегії. Формування індивідуального стилю кожного поета групи супроводжувалося непростим пошуком актуальних засобів і виявилось у конфлікті між старших поколінням діаспорного письменницького середовища і молодшими поетами, які врешті й сформували Нью-Йоркську Групу. Юрій Тарнавський від появи дебютної збірки виявив себе як експериментатор, що обирає шлях деструкції та спрощення поетичної мови. Вибір Ю. Тарнавського мав суттєве значення для пошуків власного поетичного голосу інших учасників групи, закрема Богдана Бойчука і Богдана Рубчака. Однак Б. Рубчак все ж обрав шлях синтезу новаторства і традиції та поетичного діалогу з уже канонізованими іменами української літератури.

${ }^{34}$ Т. Ш е в ч е н к о, Кобзар, Київ 1983, с. 284.

${ }^{35}$ Ю. Т а р н а в с ь к и й, Поезії про нішзо..., зазнач. праця, с. 11.

${ }^{36}$ G. G r a b o w i c z, The Voices of Ukrainian Émigré Poetry, [in:] "Canadian Slavonic Papers" 1986, no. 28, p. 168. 